\title{
Spider Diversity (Arachnida: Araneae) in Different Ecosystems of the Western Ghats, Wayanad Region, India
}

\section{Sruthi Rajeevan ${ }^{1}$, Smija Moorkoth Kunnath $^{1 *}$, Thresiamma Varghese ${ }^{2}$, Prasadan Puthanpurayil Kandambeth ${ }^{1}$}

\author{
${ }^{1}$ Department Of Zoology, Kannur University, Manathavady Campus, Wayanad 670 645, Kerala, India; ${ }^{2}$ Centre \\ For Ecological Studies, Indian Institute Of Science, Bangalore 560 012, Karanataka, India.
}

\begin{abstract}
Spiders are key components of all ecosystems in which they live and considered to be useful indicators of the overall species richness and health of terrestrial communities. However, spiders of the Western Ghats are poorly explored group and detailed information about their systematics, diversity and ecology is scarce. The present study is an attempt to investigate the spider faunal diversity in the selected habitats in the Western Ghats of North Wayanad region, Kerala, India. A total of 150 species belonging to 73 genera under 20 families were recorded from the selected habitats. Kartikulam forest reserve (Site D) showed the highest species richness and lowest species richness was recorded from Mananthavady region (Site A). Guild structure analysis of the collected spiders revealed seven functional groups viz. stalkers, orb-web builders, ambushers, space-web builder, ground runners, foliage runners and sheet-web builders. To conclude, the highest species richness is correlated with flora and fauna in these sites. The knowledge generated from the present study gives valuable and updated information on diversity of species of Western Ghats and the data can be used for future research on spider fauna.
\end{abstract}

Keywords: Forest Habitat, Plantations, Riparian Ecosystem, Species Richness, Spider, Western Ghats

Editor | Muhammad Nauman Zahid, Quality Operations Laboratory, University of Veterinary and Animal Sciences, Lahore, Pakistan.

Received | February 26, 2019 Accepted | April 27, 2019; Published | July 09, 2019

*Correspondence | Smija Moorkoth Kunnath, Department Of Zoology, Kannur University, Manathavady Campus, Wayanad 670 645, Kerala, India; Email: smijamkkunnath@gmail.com

Citation | Rajeevan S, Kunnath SM, Varghese T, Kandambeth PP (2019). Spider diversity (arachnida: araneae) in different ecosystems of the western ghats, wayanad region, india. S. Asian J. Life Sci. 7(2): 29-39.

DOI | http://dx.doi.org/10.17582/journal.sajls/2019/7.2.29.39

ISSN | 2311-0589

Copyright (C 2019 Rajeevan et al. This is an open access article distributed under the Creative Commons Attribution License, which permits unrestricted use, distribution, and reproduction in any medium, provided the original work is properly cited.

\section{INTRODUCTION}

$\mathrm{S}^{\mathrm{s}}$ piders are a diverse group of terrestrial predators, although generalizations about habitat use by spiders are complicated by their wide diversity in foraging strategies (Goldsbrough et al., 2004). They form one of the ubiquitous groups of predaceous organisms in the Animal Kingdom (Raiz et al., 2018). They can be used as successful biological indicators to assess the ecosystem health as they can be easily identified and are differently responsive to natural and anthropogenic disturbances (Pearce and Venier, 2006). This is the most diverse, female dominated and entirely predatory order in the arthropod world. Evidently, they are key components of all ecosystems in which they live (Bennett, 2001).
As spiders are general predators, they are of immense economic importance to man because of their ability to suppress pest abundance in agro-ecosystems. The population densities and species abundance of spider communities in agricultural fields can be as high as that in natural ecosystems (Mathew et al., 2014). In spite of this, they have not been treated as an important biological control agent, since very little is known of the ecological role of spiders in pest control (Fahad et al., 2015). There is a growing concern over the adverse effects of agricultural intensification on biodiversity in agricultural areas (Swift et al., 1996; Krebs et al., 1999). Despite their size, the ecological importance of spiders is undeniable as they are abundant predators of other forest arthropods (Scharff et al., 2003). Spiders are one of the most varied and functionally important preda- 
tors regulating the terrestrial arthropod population, thereby, making them effective biological control agents in ecosystems. Thus their high abundance and high diversity in almost all microhabitats, and foraging strategies coupled with the advantage of easy collection allow for their effective monitoring in the environment. Spiders are gaining importance as ecological indicators due to their extreme sensitivity to natural conditions and disturbances. However, despite their fundamental roles in most natural ecosystems, they have largely been ignored in conservational studies (Pearce and Venier, 2006).

India is one of the mega diversity countries in the world with only $2.4 \%$ of the world's land area, harbours $7-8 \%$ of all recorded species, counting over 45,000 species of plants and 91,000 species of animals (Pande and Arora, 2014). In India, 1686 species belonging to 438 genera of 60 families of spiders are reported (Keswani et al., 2013). Western Ghats, being one of the global hotspots of biodiversity, supports an enormous vegetal wealth and the entire Western Ghats biogeographic region is a major genetic estate with an enormous biodiversity of ancient lineage. Anthropogenic factors are posing serious threats to the biodiversity of Western Ghats. Land use changes in the Western Ghats over the last century caused by agricultural expansion; conversion to plantations and infrastructural projects have resulted in loss of forests and grasslands (Pius et al., 2015). Studies looking at the effects of forest fragmentation and disturbance have tended to focus on vertebrate groups particularly birds and mammals and plants (Rahman et al., 2011; Korad, 2014; Jhenkhar et al., 2016). There has been a paucity of research on invertebrates in the Western Ghats especially in relation to habitat disturbances and fragmentation (Kapoor, 2008; Mubeen and Basavarajappa, 2018).

Spiders are an important albeit poorly studied group of arthropods that play a major role in the regulation of other invertebrate populations in most ecosystems (Russell-Smith, 1999). Despite their documented ecological role in many ecosystems, high diversity and threats, spiders have received little attention from the conservation community (Sebastian et al., 2005). In the context of conservation planning efforts, preservation of spider diversity requires an understanding of the patterns of diversity on an appropriate regional scale (Uniyal and Shrivastava, 2012). Though spiders form one of the most ubiquitous and diverse group of organisms existing in Kerala, their study remained largely neglected. The present study is an attempt to investigate the spider diversity of selected habitats of Wayanad region of the Western Ghats, Kerala.

\section{MATERIALS AND METHODS}

The present study explored the diversity of spiders in different habitats of the Western Ghats, Wayanad region. The investigation was carried out during the period from January 2018 to December 2018.

\section{STUdy AREA}

Wayanad district is one of the hill stations of Kerala set high on the Western Ghats with altitudes ranging from 700 to $2100 \mathrm{~m}$. The $2131 \mathrm{~km}^{2}$ area of Wayanad is rich with agricultural fields, plantations and forest cover. The following habitats were selected for the present study (Figure 1):
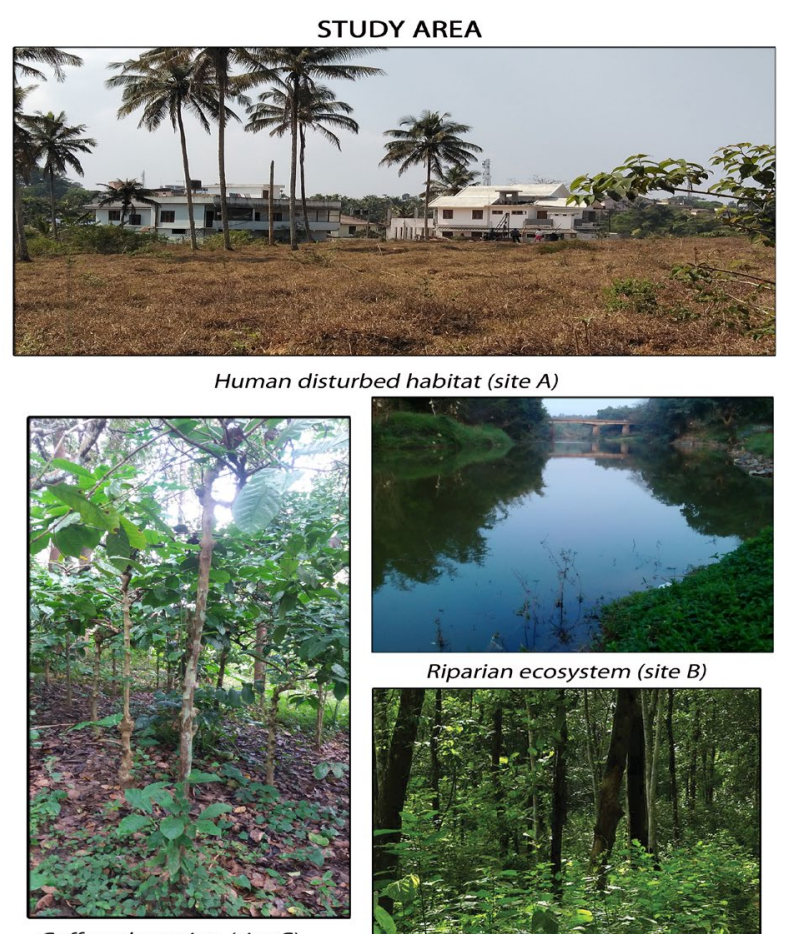

Coffee plantation (site $C$ )

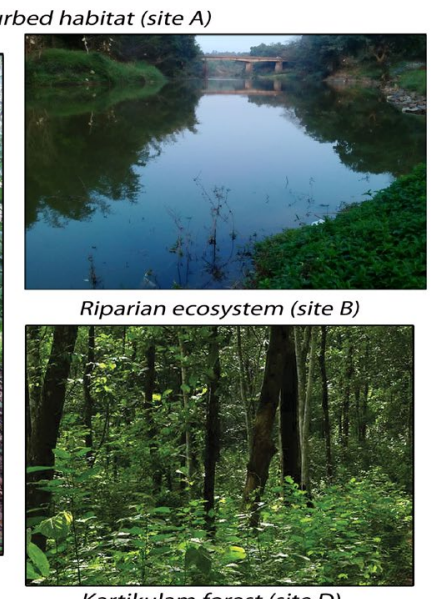

Figure 1: Study sites

1. SITE A - Human disturbed habitat in Mananthavady Mananthavady municipality is in the Wayanad district which is $3.79 \%$ urbanised.

\section{SITE B - Riparian ecosystems in Peruvaka}

Kabani River, one of the three east flowing rivers of Kerala, is an important tributary of the river Cauvery. Peruvaka is a small countryside along the banks of Kabani. Banana and ginger plantations are maintained in the banks of the stream. Farmers use chemical pesticides, weedicides and fertilizers in their agriculture lands.

\section{SITE C - Coffee plantations in Koilery}

Koilery, a small village located about $7.9 \mathrm{~km}$ away from Mananthavady and is rich in agricultural fields and plantations. Robusta is the most popular variety of coffee being cultivated here. Inorganic fertilizers are being used in this field.

\section{SITE D - Undisturbed forests in Kartikulam}

Kartikulam Reserve is a forest reserve in the northwest 
of Edakod and Chozhapurath Vayal. The forest is rich in flora and fauna. It comes under the Begur forest range, Wayanad, Kerala.

\section{Collection}

The spiders were collected during the study period from four different habitats of Wayanad region of the Western Ghats. The following methods were used to collect samples.

Visual Search Method: This method is also called "Hand Collection Method". Spiders were spotted on the flowers, folded leaves, under the leaflets, ground, shrubs, and on the bark. Spiders were easily collected by driving them into a dry container. Collections of most web-building species were made early in the morning. Keen observation is essential for the visual search method.

Inverted Umbrella Method: In this method, an inverted umbrella was placed below flowering plants and shrubs and the branches were shaken thoroughly. Spiders along with insects fell into the inverted umbrella. Spiders were transferred into collecting vials after removing other insects from the umbrella.

Kerchief Method: This method was used for collecting running and wandering spiders, especially those belonging to the families Lycosidae and Salticidae. An open kerchief was thrown over the running spider, which was then carefully caught in the folds of kerchief.

Sweep Net Method: This is one of the simplest methods followed to collect spiders. The ideal habitat for using sweep net was one with grasses and flowers. The habitats were swept as many times as necessary to get a good sample. Spiders that fell into the net were collected before they were escaped.

Small specimens were photographed by using a stereo zoom microscope and large specimens were photographed by using Samsung galaxy J5 (15MP camera).

\section{Preservation}

The specimens were preserved in 70\% isopropyl alcohol.

\section{IDENTIFICATION}

The specimens were identified with the help of experts in spider taxonomy and taxonomic keys of spiders (Tikader, 1987; Murphy and Murphy, 2000; Dippenaar, 2002).

\section{Guild Classification}

Ecological characteristics relating to foraging manner, nature of web, prey species, microhabitat use, and daily activity were subjected to guild classification. The spider guild classification was composed according to the families collected during the study. Designation of spider guild was based on the ecological characteristic known for the family (Young and Edwards, 1990; Cardoso et al., 2011).

\section{RESULTS}

The present study focused on the spider diversity of four different habitats of the Western Ghats, Wayanad region, Kerala, India. A total of 150 species belonging to 73 genera under 20 families were recorded from the selected habitats. Salticidae was the dominant family constituting 44 species under 19 genera, followed by Araneidae (22 species), Theridiidae (14 species), Thomisidae (9 species), Oxyopidae (9 species), Lycosidae (7 species), Tetragnathidae (7 species), Corrinnidae (5 species), Sparassidae (5 species), Eutichuridae (5 species), Nephilidae (4 species), Uloboridae (4 species), Pisauridae (3 species), Linyphiidae (3 species), Hersiliidae (3 species), Clubionidae (1 species), Ctenidae (1 species), Mimetidae (1 species), Pholcidae (1 species) and Theraphosidae (1 species).

Highest species richness was recorded at Kartikulam reserve (Site D) with 70 species belonging to 14 families. Coffee plantation (Site C) exhibited second highest species richness with 36 species belonging to eight families. Riparian ecosystem (Site B) depicted third highest level of species richness with 28 species belonging to eight families. About 17 species belonging to nine families were recorded from Mananthavady (Site A). So in the present investigation, the highest species richness was observed at Kartikulam reserve as compared to other habitats (Figures 2-11).

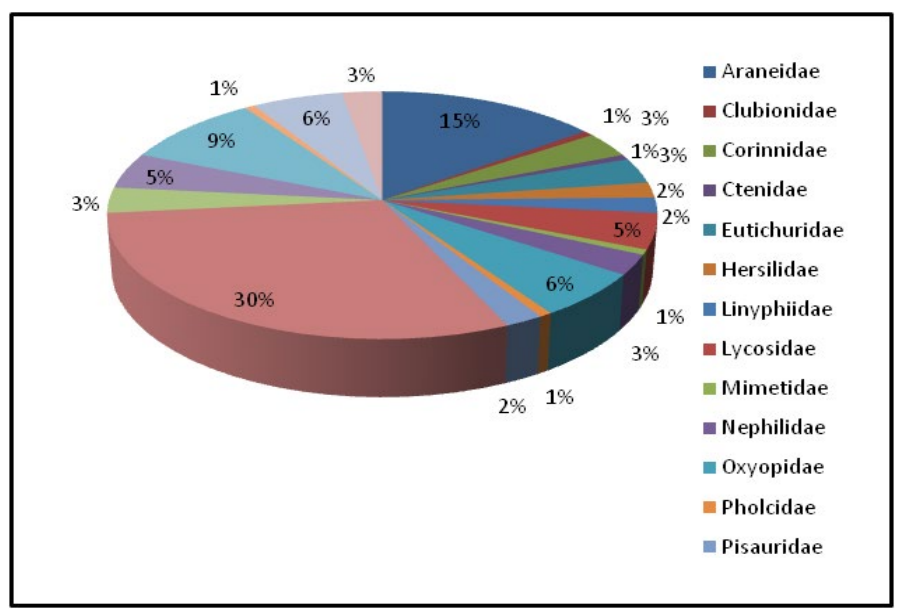

Figure 2: Species distribution in different families found in Western Ghats region, Wayanad

The spiders belonged to seven functional groups based on their foraging mode. Stalkers were the dominant feeding guild with $36 \%$, followed by orb-web builders (24.6\%), ambushers (12.6\%), space-web builders (10\%), ground run 
Disturbed area Riparian ecosystem Coffee plantation Forest

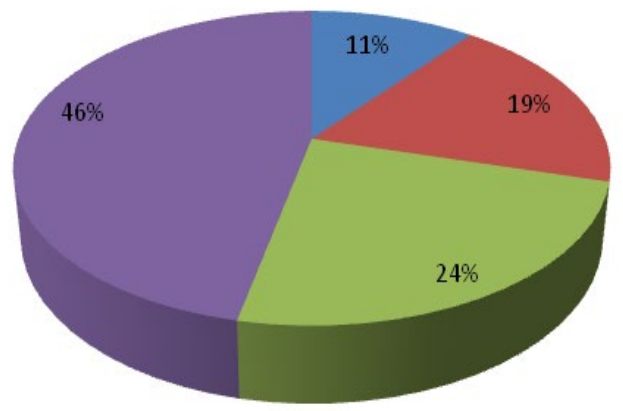

Figure 3: Comparison of spider families recorded from four different habitats of Western Ghats, Wayanad

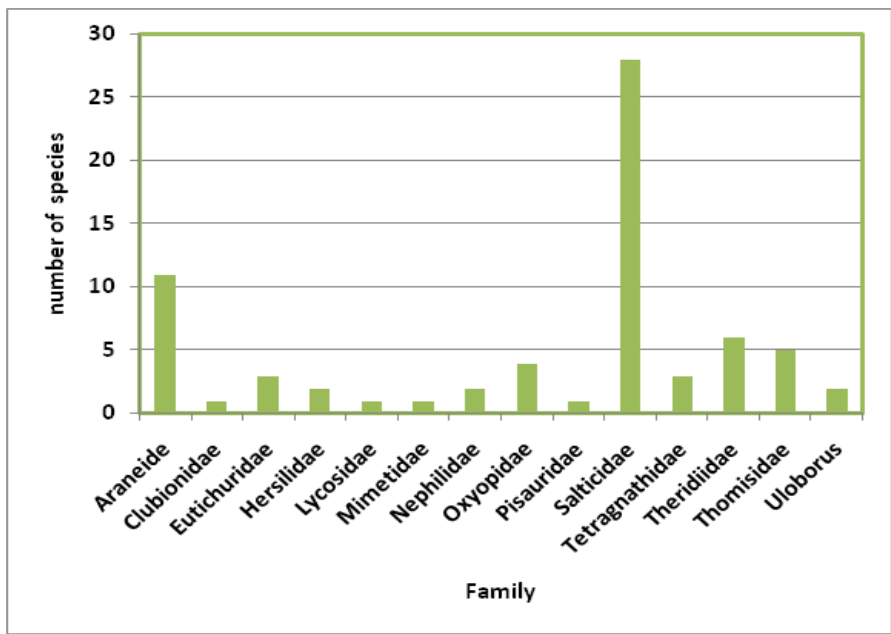

Figure 4: Number of species recorded from site D, Kartikulam forest reserve

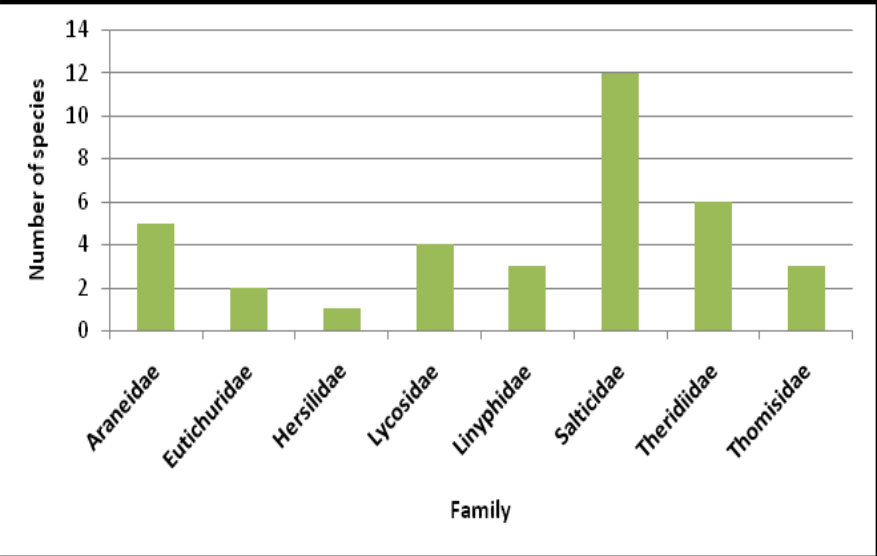

Figure 5: Number of species recorded from site C, coffee plantation, Koilery

ners $(8.6 \%)$, foliage runners $(6 \%)$ and sheet-web builders (2\%). The dominant guild (Stalkers) was composed of 53 species of the families, Salticidae and Oxyopidae. Orb-web builders constituted 37 species under the families, Araneidae, Tetragnathidae, Uloboridae and Nephilidae (Table 1). In the present study, the habitat preferences of the vari

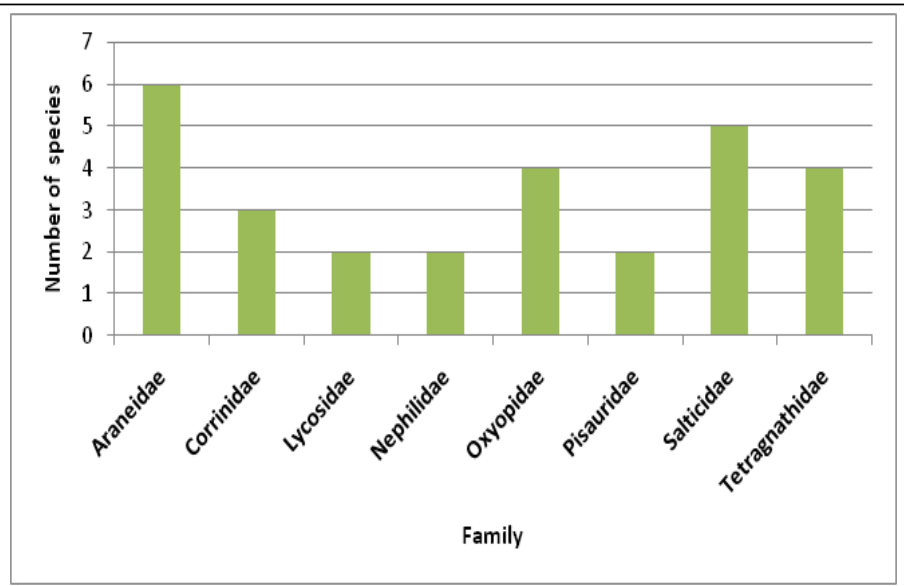

Figure 6: Number of species recorded from site B, riparian ecosystem, Peruvaka

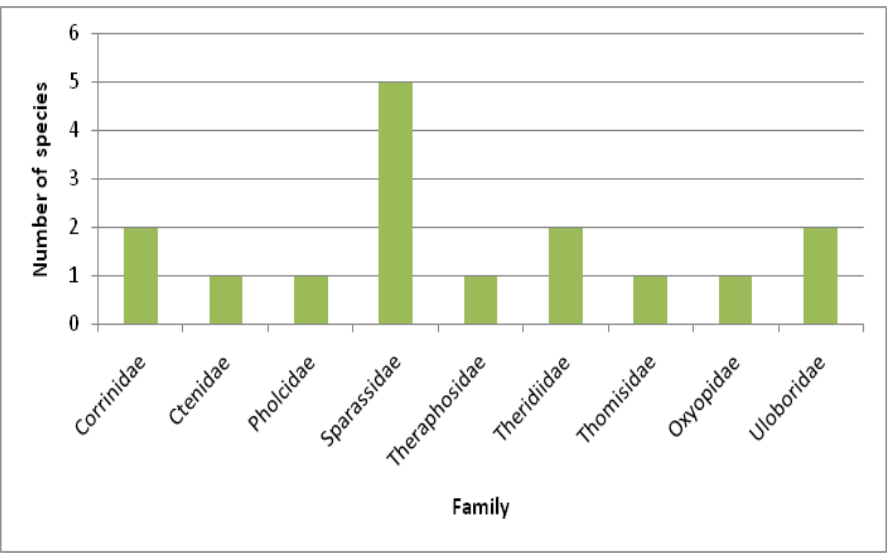

Figure 7: Number of species recorded from site A, disturbed area, Mananthavady

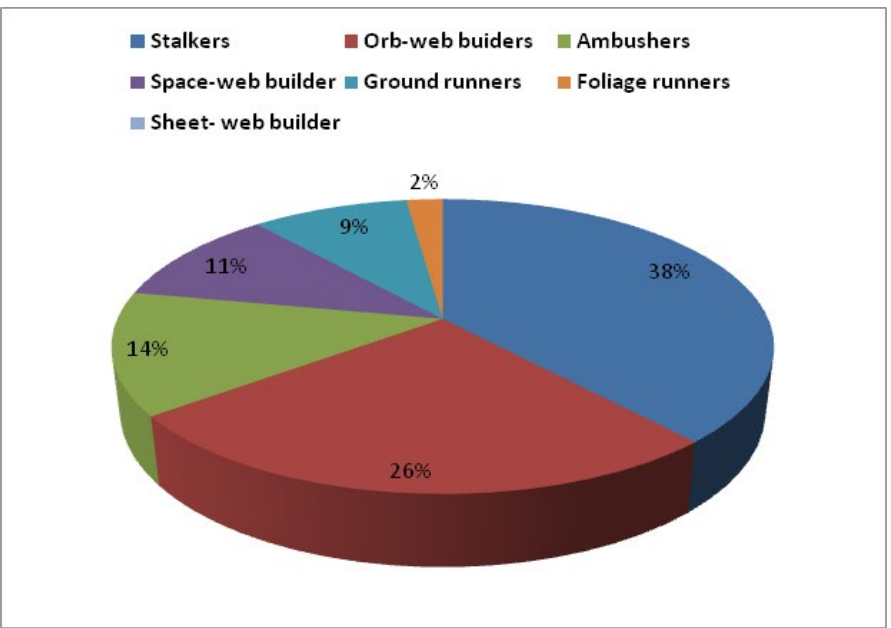

Figure 8: Guild structure analysis of spiders recorded from Western Ghats, Wayanad

ous spider species were also analyzed. Spiders preferred to live in different habitats. Species belonging to Tetragnathidae, Oxyopidae, Theridiidae, Araneidae families were mainly found in vegetation. Tetragnathids are long legged thin bodied spiders found on the webs along the banks of 

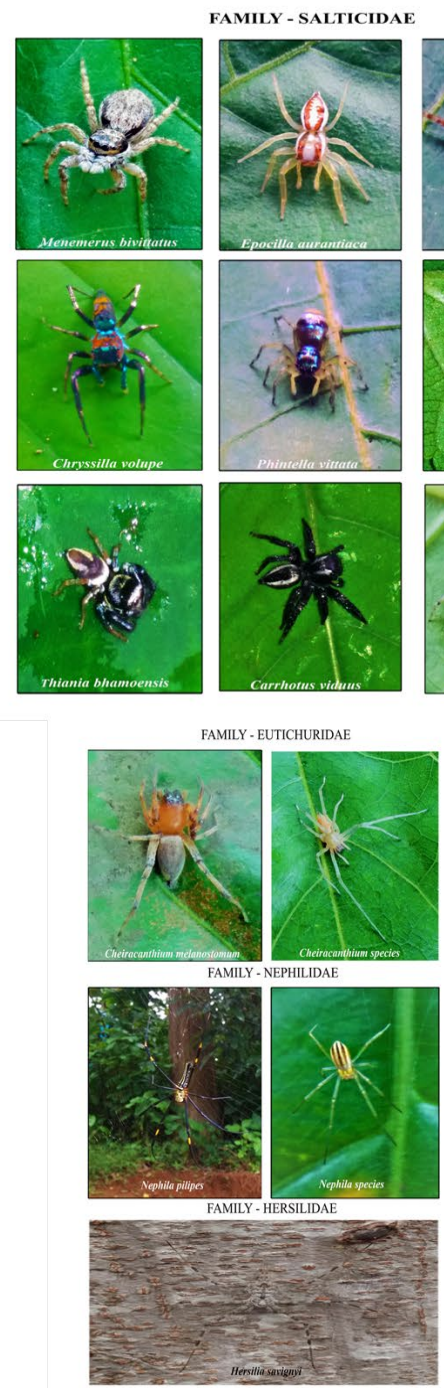
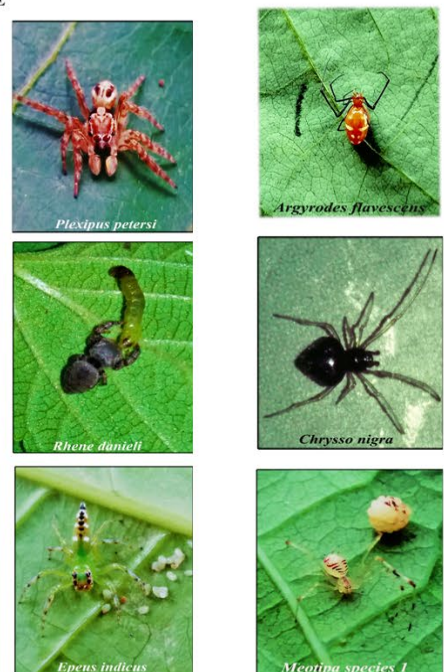

AMILY - PISAURIDAE
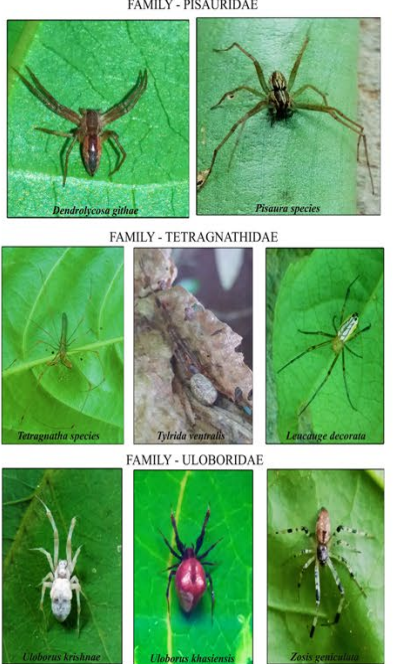

FAMILY - THERIDIIDAE
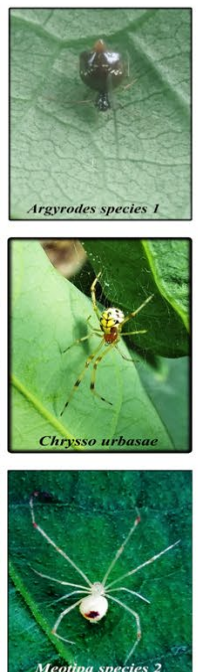
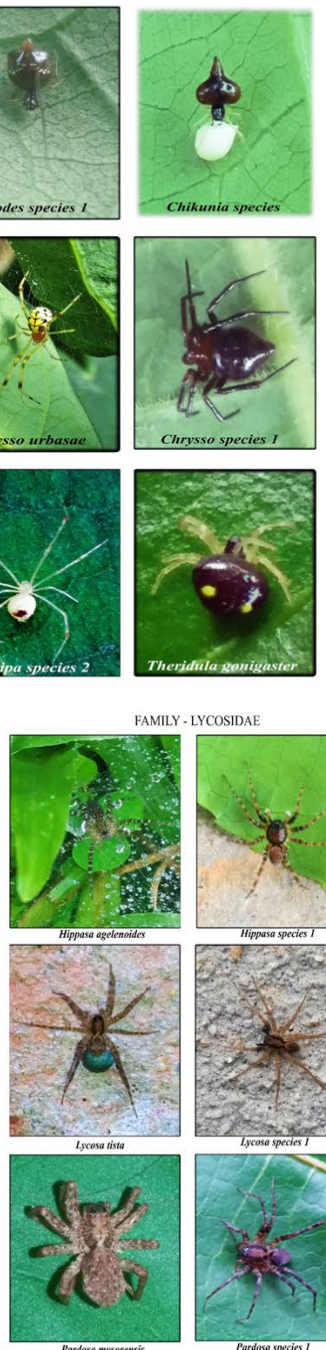
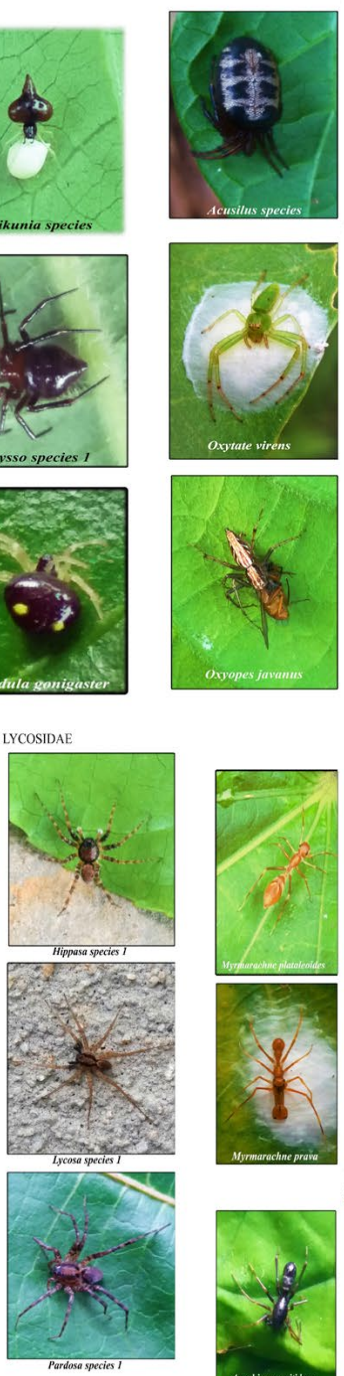

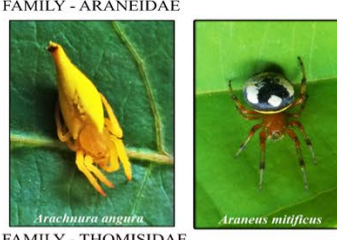

FAMILY - THOMISIDA
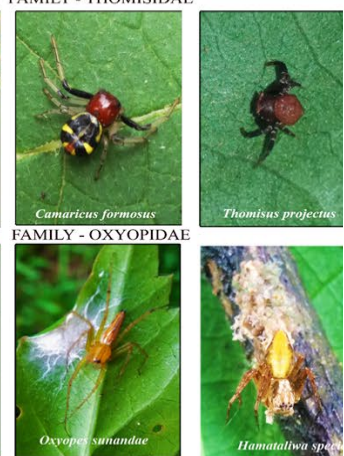

FAMTIY - SALTICDDAE
(Ant- mimicking spiders)

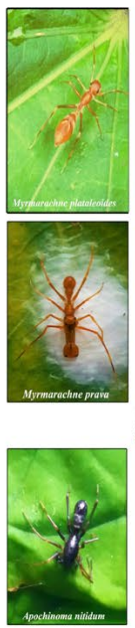

(2)
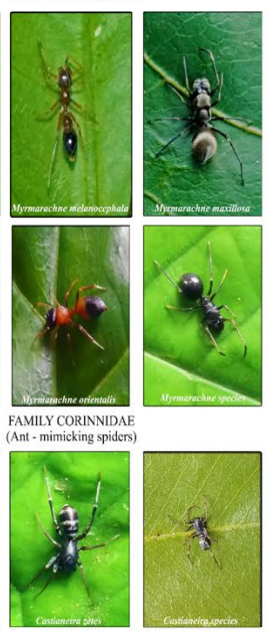

Figure 9: Species diversity in different families found in Western Ghats, Wayanad
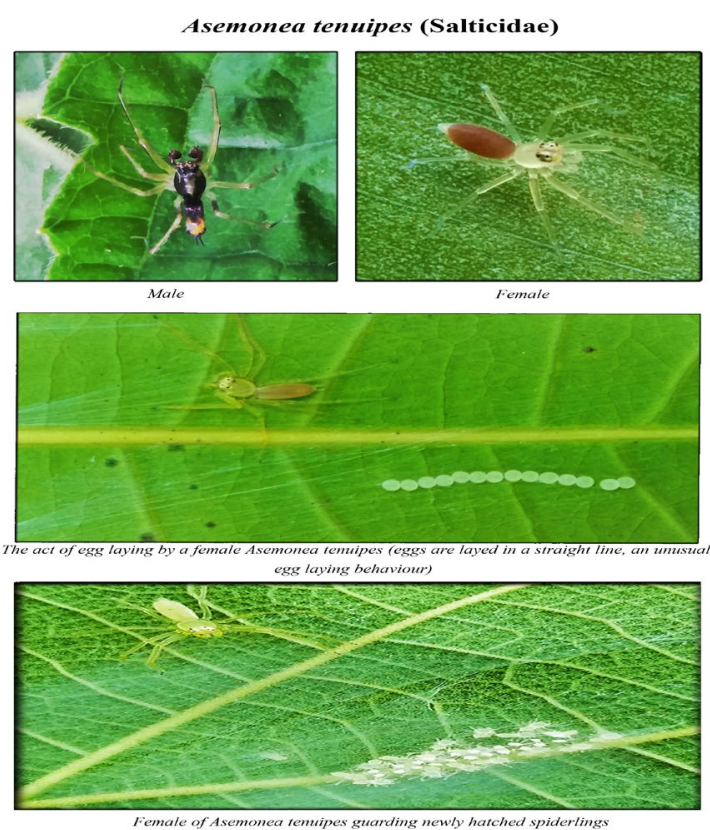

Figure 10: Female of Asemonea tenuipes guarding the eggs and newly hatched spiderlings

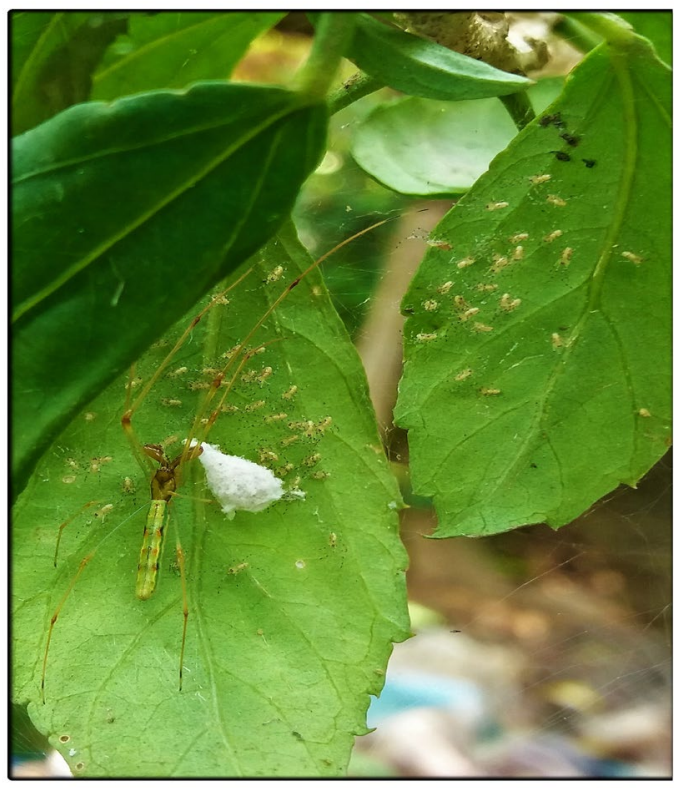

Female of Tetragnatha sp. (Tetragnathidae) guarding the egg-sac and newly hatched

Figure 11: Female of Tetragnatha (Tetragnathidae) guarding young ones 
Table 1: Systematic list of recorded spiders from ecosystems

\begin{tabular}{|c|c|c|}
\hline Family & Species & Guild \\
\hline \multirow{22}{*}{ Araneidae } & Arachnura angura & Orb-web builders \\
\hline & Araneus sp. 1 & Orb-web builders \\
\hline & Argiope anasuja & Orb-web builders \\
\hline & Argiope pulchella & Orb-web builders \\
\hline & Argiope sp.1 & Orb-web builders \\
\hline & Cyrtophora cicatrosa & Orb-web builders \\
\hline & Cyrtophora sp.1 & Orb-web builders \\
\hline & Cyrtarachne sp. & Orb-web builders \\
\hline & Eriovixia excelsa & Orb-web builders \\
\hline & Eriovixia lagleizi & Orb-web builders \\
\hline & Eriovixia sp.1 & Orb-web builders \\
\hline & Eriovixia sp.2 & Orb-web builders \\
\hline & Gasteracantha geminata & Orb-web builders \\
\hline & Neoscona adianta & Orb-web builders \\
\hline & Neoscona bengalensis & Orb-web builders \\
\hline & Neoscona crucifera & Orb-web builders \\
\hline & Neoscona mukerjei & Orb-web builders \\
\hline & Neoscona vigilans & Orb-web builders \\
\hline & Neoscona sp.1 & Orb-web builders \\
\hline & Neoscona sp. 2 & Orb-web builders \\
\hline & Neoscona sp.3 & Orb-web builders \\
\hline & Parawixia dehaani & Orb-web builders \\
\hline \multirow[t]{2}{*}{ Clubionidae } & Clubiona sp.1 & Foliage runners \\
\hline & Apochinoma sp.1 & Ground runners \\
\hline \multirow[t]{4}{*}{ Corinnidae } & Castianeira zetes & Ground runners \\
\hline & Castianeira sp.1 & Ground runners \\
\hline & Castianeira sp.2 & Ground runners \\
\hline & Oediognatha sp.1 & Ground runners \\
\hline Ctenidae & Ctenus cochinensis & Ground runners \\
\hline \multirow{5}{*}{ Eutichuridae } & Cheiracanthium melanostomum & Foliage runners \\
\hline & Cheiracanthium murrinum & Foliage runners \\
\hline & Cheiracanthium sp.1 & Foliage runners \\
\hline & Cheiracanthium sp.2 & Foliage runners \\
\hline & Cheiracanthium sp.3 & Foliage runners \\
\hline \multirow[t]{3}{*}{ Hersilidae } & Hersilia striata & Foliage runners \\
\hline & Hersilia sp.1 & Foliage runners \\
\hline & Murrica triangularis & Foliage runners \\
\hline \multirow[t]{7}{*}{ Lycosidae } & Hippasa agelenoides & Ground runners \\
\hline & Hippasa sp.1 & Ground runners \\
\hline & Lycosa tista & Ground runners \\
\hline & Lycosa sp.1 & Ground runners \\
\hline & Lycosa sp.2 & Ground runners \\
\hline & Pardosa mysorensis & Ground runners \\
\hline & Pardosa sp.1 & Ground runners \\
\hline
\end{tabular}


Lyniphidae

Oxyopidae

Salticidae

Mimetidae

Nephilidae

Pholsidae

Pisauridae
Lyniphia sp.1

Nereine sundaica

Nereine sp.1

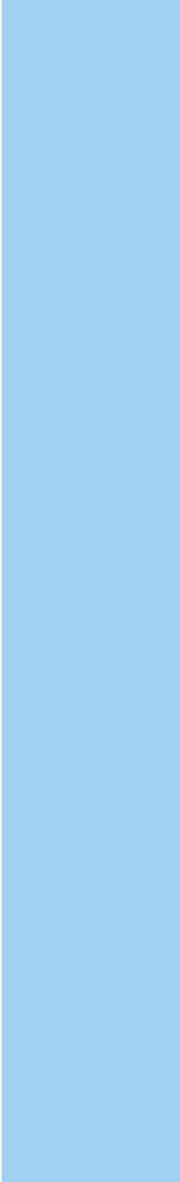

Oxyopes javanus

Epeus indicus
Mimetus sp.1

Herennia multipuncta

Nephila pilipes

Nephila sp.1

Nephila sp. 2

Hamadruas sp.1

Hamataliwa sp.1

Hamataliwa sp.2

Hamataliwa sp.3

Oxyopes sunandae

Oxyopes sp. 1

Oxyopes sp. 2

Oxyopes sp. 3

Pholcus sp.1

Dendrolycosa githae

Perenthis venusta

Pisaura sp.

Asemonea tenuipes

Bavia insularis

Bavia sp.1

Carrhotus viduus

Chalcotropis pennata

Chacotropis sp. 1

Chalcotropis sp.2

Chrysilla volupe

Epeus flavobilineatus

Epeus tener

Epeus sp.1

Epeus sp. 2

Epocilla aurantiaca

Epocilla calcarata

Hasarius adansoni

Hyllus semicupreus

Myrmarachne cornuta

Myrmarachne japonica

Myrmarachne maxillosa

Myrmarachne melanocephala

Myrmarachne orientales

Myrmarachne plataleoides

Myrmarachne prava

Myrmarachne formicaria

Myrmarachne sp.1
Sheet-web builder

Sheet-web builder

Sheet-web builder

Ambushers

Orb-web builders

Orb-web builders

Orb-web builders

Orb-web builders

Stalkers

Stalkers

Stalkers

Stalkers

Stalkers

Stalkers

Stalkers

Stalkers

Stalkers

Space-web builder

Ambushers

Ambushers

Ambushers

Stalkers

Stalkers

Stalkers

Stalkers

Stalkers

Stalkers

Stalkers

Stalkers

Stalkers

Stalkers

Stalkers

Stalkers

Stalkers

Stalkers

Stalkers

Stalkers

Stalkers

Stalkers

Stalkers

Stalkers

Stalkers

Stalkers

Stalkers

Stalkers

Stalkers

Stalkers 


\begin{tabular}{|c|c|c|}
\hline & Myrmarachne sp. 2 & Stalkers \\
\hline & Myrmarachne sp.3 & Stalkers \\
\hline & Myrmarachne sp.4 & Stalkers \\
\hline & Myrmarachne sp. 5 & Stalkers \\
\hline & Myrmarachne sp.6 & Stalkers \\
\hline & Plexipus paykuli & Stalkers \\
\hline & Plexipus petersi & Stalkers \\
\hline & Rhene danieli & Stalkers \\
\hline & Rhene flavigera & Stalkers \\
\hline & Rhene rubrigera & Stalkers \\
\hline & Siler semiglaucus & Stalkers \\
\hline & Telamonia dimidiata & Stalkers \\
\hline & Telamonia elegans & Stalkers \\
\hline & Thiania bhamoensis & Stalkers \\
\hline & Menemerus bivittatus & Stalkers \\
\hline & Phintella vittata & Stalkers \\
\hline & Piranthus sp.1 & Stalkers \\
\hline & Stenaelurillus sp.1 & Stalkers \\
\hline & Salticid sp.1 & Stalkers \\
\hline & Heteropoda venatoria & Ambushers \\
\hline & Olios sp.1 & Ambushers \\
\hline Sparassidae & Sparassid sp.1 & Ambushers \\
\hline & Sparassid sp. 2 & Ambushers \\
\hline & Sparassidsp.3 & Ambushers \\
\hline & Leucauge decorata & Orb-web builders \\
\hline & Leucauge tessellata & Orb-web builders \\
\hline Tetragnathidae & Tetragnatha mandibulata & Orb-web builders \\
\hline & Tetragnatha sp.1 & Orb-web builders \\
\hline & Tetragnatha sp.2 & Orb-web builders \\
\hline & Tetragnatha sp.3 & Orb-web builder \\
\hline & Tylorida ventralis & Orb-web builders \\
\hline Theraphosidae & Theraphosid sp.1 & Ambushers \\
\hline & Argyrode sp.1 & Space-web builder \\
\hline & Chrysso nigra & Space-web builder \\
\hline & Chrysso urbasae & Space-web builder \\
\hline & Chrysso sp. 1 & Space-web builder \\
\hline & Meotipa sp.1 & Space-web builder \\
\hline Theridiidre & Meotipa sp.2 & Space-web builder \\
\hline inerianidae & Theridula gonigaster & Space-web builder \\
\hline & Theridion manjitar & Space-web builder \\
\hline & Trwaitesia sp.1 & Space-web builder \\
\hline & Coleosoma bluntum & Space-web builder \\
\hline & Nibonbimea mundula & Space-web builder \\
\hline & Parasteatoda sp.1 & Space-web builder \\
\hline & Phycosoma sp.1 & Space-web builder \\
\hline & Theridiid sp. & Space-web builder \\
\hline
\end{tabular}




\begin{tabular}{lll}
\hline & Amyciaea forticeps & Ambushers \\
\hline Amyciaea sp. & Ambushers \\
\hline camaricus formosus & Ambushers \\
\hline Thomisus lobosus & Ambushers \\
\hline Thomisus projectus & Ambushers \\
\hline Thomisus telenganensis & Ambushers \\
\hline Thomisus sp. & Ambushers \\
\hline Thomisus sp. & Ambushers \\
\hline Oxytate virens & Ambushers \\
\hline \multirow{3}{*}{ Uloboridae } & Uloborus khasiensis & Orb-web builders \\
& Uloborus krishnae & Orb-web builders \\
\hline Uloborus sp.1 & Orb-web builders \\
\hline Zosis geniculata & Orb-web builders \\
\hline
\end{tabular}

Table 2: List of ant-mimicking spiders collected

\begin{tabular}{|lll|}
\hline S1.NO & SPECIES & FAMILY \\
\hline 1 & Apochinoma sp. & Corinnidae \\
\hline 2 & Castianeira zetes & Corinnidae \\
\hline 3 & Castianeira sp. 1 & Corinnidae \\
\hline 4 & Castianeira sp. 2 & Corinnidae \\
\hline 5 & Myrmarachne cornuta & Salticidae \\
\hline 6 & Myrmarachne japonica & Salticidae \\
\hline 7 & Myrmarachne maxillosa & Salticidae \\
\hline 8 & Myrmarachne melanocephala & Salticidae \\
\hline 9 & Myrmarachne orientales & Salticidae \\
\hline 10 & Myrmarachne plataleoides & Salticidae \\
\hline 11 & Myrmarachne prava & Salticidae \\
\hline 12 & Myrmarachne formicaria & Salticidae \\
\hline 13 & Myrmarachne sp.1 & Salticidae \\
\hline 14 & Myrmarachne sp.2 & Salticidae \\
15 & Myrmarachne sp.3 & Salticidae \\
\hline 16 & Myrmarachne sp.4 & Salticidae \\
\hline 17 & Myrmarachne sp.5 & Salticidae \\
\hline 18 & Myrmarachne sp.6 & Salticidae \\
\hline 19 & Amyciacea forticeps & Thomisidae \\
\hline 20 & Amyciacea sp. & Thomisidae \\
\hline
\end{tabular}

rivers. Oxyopids were mainly found on the grasses. Theridiids are usually found at the bottom of leaves. On the other hand, thomisid spiders were found on flowering plants. Cyrtophora cicatrosa was found on the three dimensional web on small herbs. Nephila pilipes is one of the biggest spiders recorded in the study; it builds a large sized orbweb between adjacent trees. Arachnura angura is a scorpion tailed, very rare species found on the leaves and it mimics colourful petals. Hersilia striata and Murrica triangularis found on the tree barks and they showed clear camouflage. Hippasa agelenoides is found in funnel shaped webs and retreats over holes in the ground at the base of the shrubs a- nd active during early morning. Field observations revealed that Telamonia dimidiata, Plexipus petersi, Bavia insularis ofthe family Salticidae and Oxyopes sunandae of the family Oxyopidae were recorded as superior predators of the four ecosystems.

We recorded a rare egg laying behaviour in spiders of the family, Salticidae. Generally, jumping spiders are the group of spiders that constitute the family, Salticidae and they are selective about where they oviposit in nature. Asemoni atenuipes, of the family Salticidae, lays eggs in a straight line and it also constructs web in the form of silken platform which is made up of very loose silk threads. The spider also uses the same structures for resting and ovipositing. Interestingly, the present study recorded 20 species of ant-mimicking spiders from different ecosystems. They represented the families such as Corinnidae, Salticidae and Thomisidae. Most of the ant-mimicking spiders were obtained from forest habitat (8 species) and less from riparian ecosystem (7 species) and plantations (5 species) (Table 2 ) (Figures 9, 10 and 11).

\section{DISCUSSION}

Spider diversity, distribution and their insect feeding habits play an important role in the balance of nature (Yong and Edward, 1990). They are potential biological indicators of natural habitats and are used for determining how communities react to environmental changes or disturbances (Marc and Canard, 1997). The status of spider diversity is an important constraint to evaluate the community level of biological organization. Higher species diversity is an indicator of a healthier and complex community because a greater variety of species allows more interactions, hence greater system stability which in turn indicates good environmental conditions (Hill, 1973). 
In the current study, a total of 150 species belonging to 73 genera under 20 families were recorded from the selected habitats of Wayanad region. Salticidae was the dominant family constituting 44 species under 19 genera. Highest species richness was recorded at Kartikulam reserve (Site D) with 70 species belonging to 14 families. This habitat showed rich floral (trees and shrubs) and faunal (butterflies, moths, beetles, dragon flies and ants) diversity which is a key factor to build microhabitats for a wide variety of spider species. Coffee plantation (Site C) exhibited second highest species richness with 36 species belonging to eight families. This area also holds a wide range of plants and animals. These varied habitats provide a greater array of microhabitats, microclimatic features, alternative food sources, retreat sites and web attachment sites for spiders. Riparian ecosystem (Site B) depicted third highest level of species richness with 28 species belonging to eight families. The region mainly comprised of banana and ginger plantations and the low species richness may be attributed to the usage of chemical pesticides on the banks of the river. About 17 species belonging to nine families were recorded from Mananthavady (Site A) and vegetation cover was relatively low in this area. So in the present investigation, the highest species richness was observed at Kartikulam reserve (Site D). This may be due to increased vegetation in these areas which lead to the increase in biodiversity and ultimately leads to the greater cover and food resources for these fantastic creatures. Similar results were also reported by other authors in spider diversity studies. Sudhikumar et al. (2005) carried out studies on spider diversity of Mannavan Shola forest and reported 72 species belonging to 57 genera of 20 families. Rendon et al. (2006) studied the spider diversity in coffee plantations of Mexico and recorded 98 species belonging to 56 genera under 20 families. Jose et al. (2018) reported the diversity of spiders in Kavvayi river basin and recorded 112 species belonging to 81 genera and 21 families. The diversity of anthropogenic spiders in the city of Chilpancingo, Guerrero, Mexico was studied by Rodríguez et al. (2015) and recorded 63 species belonging to 49 genera under 21 families. Bonn and Kleinwächter (1999) suggested that species richness increased with habitat divergence and interrelated sets of species traits.

In the present study, seven functional groups were identified based on their foraging mode. Stalkers were the dominant feeding guild with $36 \%$, and followed by orb-web builders (24.66\%). Similarly, Sebastian et al. (2005) recorded seven different foraging guilds in the irrigated rice ecosystem of Kerala. Adarsh and Nameer (2013) recorded spider fauna of Kerala Agricultural University, Southern India and the feeding guild structure analysis revealed seven types of functional groups. By contrast, Pandit and Pai (2017) documented the spider fauna from the Taleigao plateau, Goa and they belonged to nine foraging guilds.
Spiders of the families like Tetragnathidae, Oxyopidae, Theridiidae, Araneidae were found mainly on trees, shrubs and herbs in our study. Studies have demonstrated that the spider habitat selection is affected by a variety of biotic and abiotic factors together with the architectural attributes of the habitat. Architectural attributes include size, shape and spatial arrangement of substrate used by spiders (Utez, 1991; Hawksworth and Kalin-Arroyo 1995). Ried and Miller (1989) suggest that structurally more complex habitat types can support a more diverse spider community. In general, spiders have preferences for humidity and temperature and these factors limit them to areas within the range of their physiological tolerances (Pandit and Pai, 2017). The results of the present study and several other observations led to the conclusion that habitat structure and environmental factors may be crucial in determining the composition of spider community of the area. Therefore, documenting spider diversity patterns can provide important information to justify the conservation significance of the ecosystem.

\section{ACKNOWLEDGEMENTS}

The authors greatly acknowledge the support of the Kerala Forest Department, North Wayanad Division for providing permission for periodical survey. The research was supported by the funding from Department of Collegiate Education (ASPIRE fellowship), Govt. of Kerala, India.

\section{CONFLICT OF INTEREST}

The authors declare that they have no conflict of interest related to the work.

\section{AUTHORS CONTRIBUTION}

Dr Smija M K, Dr Thresiamma Varghese and Dr Prasadan $\mathrm{P} K$ contributed to the design and implementation of the research. Ms. Sruthi R collected and contributed the data. Dr Thresiamma Varghese helped to identify the collected specimens. Dr Smija M K contributed to the interpretation of the results. All the authors contributed to the writing of the manuscript.

\section{REFERENCES}

- Adarsh CK, Nameer PO (2015). Spiders of Kerala Agricultural University Campus, Thrissur, Kerala, India. Jo TT. 7(15): 8288-8295 https://doi.org/10.11609/jott.2468.7.15.82888295

- Bennett RG (2001). Spiders (Araneae) and araneology in British Columbia. J. Entomol. Soc. B. C. 98: 83-90.

- Bonn A, Kleinwachter M (1999). Microhabitat distribution of spider and ground beetle assemblages (Araneae, Carabidae) 
on frequently inundated river banks of the River Elbe. Z. Okologie u. Naturschutz. 8: 109-123.

- Cardoso P, Pekar S, Jocque R, Coddington JA (2011). Global patterns of guild composition and functional diversity of spiders. PloS one. 6(6): e21710. https://doi.org/10.1371/ journal.pone.0021710

- Dipp Enaar-Scho Eman AS (2002). The spider guide of Southern Africa. ARC-Plant Protection Research Institute. South Africa.

- Fahad S, Nie L, Hussain S, Khan F, Khan FA, Saud S, Wu C (2015). Rice pest management and biological control. Sust. Agric. Rev. 85-106. https://doi.org/10.1007/978-3-31916988-0_4

- Goldsbrough CL, Hochuli DF, Shine R (2004). Fitness benefits of retreat-site selection: spiders, rocks, and thermal cues. Ecology. 85(6): 1635-1641. https://doi.org/10.1890/020770

- Hawksworth DL, Kalin-Arroyo MT (1995): Magnitude and distribution of biodiversity. -In: Heywood, V.H. (ed) Global Biodiversity Assessment. United Nations Environment Programme. London: Cambridge University Press.

- Hill MO (1973). Diversity and evenness: a unifying notation and its consequences. Ecology. 54(2): 427-432. https://doi. org/10.2307/1934352

- Jhenkhar M, Jadegowda M, Cheppudira K, Ramesh MN, Amaresh K (2016). Bird Diversity Across Different Vegetation Types in Kodagu, Central Western Ghats, India. Int. J. Zool. Res. 25-36.

- Jose AC, Sudhin PP, Prasad PM, Sreejith KA. Spider Diversity in Kavvayi River Basin, Kerala, Southern India.

- Kapoor V (2008). Effects of rainforest fragmentation and shade-coffee plantations on spider communities in the Western Ghats. India. J. Insect. Conserv. 12(1): 53-68. https://doi.org/10.1007/s10841-006-9062-5

- Keswani S, Hadole P, Rajoria A (2012). Checklist of spider (Arachnida: Araneiae) from India. Ind. J. Arachnol. 2012: 1(1):2278-1587.

- Korad V (2014). Studies on diversity, distribution, and conservation of the bat fauna in Maharashtra State, India. TAPROBANICA: J. Asian Biodiversit. 6(1). https://doi. org/10.4038/tapro.v6i1.7083

- Krebs JR, Wilson JD, Bradbury RB, Siriwardena GM (1999). The second silent spring?. Nature. 400(6745): 611. https:// doi.org/10.1038/23127

- Marc P, Canard A (1997). Maintaining spider biodiversity in agro ecosystems as a tool in pest control. Agric. Ecosyst. Environ. 62(2-3): 229-235. https://doi.org/10.1016/S01678809(96)01133-4

- Mathew EV, Sudhikumar A, Sebastian PA (2014). Vertical stratification of spiders in Kuttanad rice agroecosystem. Kerala. J. Biol. Control. 28(2): 62-67.

- Mubeen M, Basavarajappa S (2018). Density, Abundance and Per Cent Occurrence of Spider Species (Arachnida: Araneae) In and Around Mysore City, Karnataka, India-A Case Study.

- Murphy F, J Murphy (2000). An Introduction to the Spiders of South East Asia. MNS, Malaysia. 624 p.

- Pande HK, Arora S (2014). India's fifth national report to the convention on biological diversity. Ministry of environment and forests, Government of India, New Delhi, 142.

- Pandit R, Pai IK (2017). Spiders of Taleigao Plateau, Goa, India. https://doi.org/10.26502/jesph.96120022

- Pearce JL, Venier LA (2006). The use of ground beetles
(Coleoptera: Carabidae) and spiders (Araneae) as bioindicators of sustainable forest management: a review. Ecological indicators. 6(4): 780-793. https://doi. org/10.1016/j.ecolind.2005.03.005

- Pius OL, Sujanapal P, Udayan PS. (2015). Diversity inventory and conservation of endemic and threatened medicinal plants of Malappuram District, Kerala. Ann. Pl. Sci. 4(03): 1022-1028.

- Rahman PM, Varma RV, Sileshi GW (2012). Abundance and diversity of soil invertebrates in annual crops, agroforestry and forest ecosystems in the Nilgiri biosphere reserve of Western Ghats, India. Agro Forest. Systems. 85(1): 165-177 https://doi.org/10.1007/s10457-011-9386-3.

- Raiz Tabasum N, Nagaraj B, Shubha Shantakumari VS, Sai Sandeep Y. Assessment Of Spider Diversity And Composition Along The Tungabhadra Irrigation Channel At Ballari, Karnataka.

- Rendón MAP, Ibarra-Núnez G, Parra-Tabla, V, GarcíaBallinas JA, Hénaut Y (2006). Spider diversity in coffee plantations with different management in Southeast Mexico. J. Arachnol. 104-112. https://doi.org/10.1636/M03-044.1

- Ried WV, KR Miller (1989). Keeping options alive: A scientific basis for conserving biodiversity. World Resources Institute, Washington D.C.

- Rodriguez-Rodriguez, SE, Solis-Catalan, KP, ValdezMondragon A (2015). Diversity and seasonal abundance of anthropogenic spiders (Arachnida: Araneae) in different urban zones of the city of Chilpancingo, Guerrero, Mexico. Rev. Mex. Biodivers. 86(4): 962-971. https://doi. org/10.1016/j.rmb.2015.09.002

- Russell-Smith A (1999). The spiders of Mkomazi Game reserve. In: Coe M, McWilliam N, Stone G, Parker M, Eds. Mkomazi: The Ecology, Biodiversity and Conservation of a Tanzanian Savanna. Royal Geographical Society, London. 197-222.

- Scharff N, Coddington JA, Griswold CE, Hormiga G, Bjørn PDP (2003). When to quit? Estimating spider species richness in a northern European deciduous forest. J. Arachn. 31(2): 246-273. https://doi.org/10.1636/01618202(2003)031[0246:WTQESS]2.0.CO;2

- Sebastian PA, Mathew MJ, Beevi SP, Joseph J, Biju CR (2005). The spider fauna of the irrigated rice ecosystem in central Kerala, India across different elevational ranges. J. Arachn. 247-255. https://doi.org/10.1636/05-08.1

- Sudhikumar AV, Mathew MJ, Sunish E, Murugesan S, Sebastian PA (2005). Preliminary studies on the spider fauna in Mannavan shola forest. Kerala, India(Araneae).

- Swift RS (1996). Organic matter characterization. Methods of Soil AnalysisPart 3-Chemical Methods, (methods of soil an3). 1011-1069.

- Tikader BK (1987). Handbook of Indian Spiders. Calcutta, Zoological Survey of India. $251 \mathrm{p}$.

- Uetz GW (1979). The influence of variation in litter habitats on spider communities.-Oecologia. (40): 29-42. https://doi. org/10.1007/BF00388808

- VP Uniyal, Aseem Shrivastava (Eds.) (2012). Arthropods and their Conservation in India (Insects \& Spiders), ENVIS Bulletin : Wildlife \& Protected Areas. Vol. 14, 2011. Printed in 2013; Wildlife Institute of India, Dehradun-248001, India.

- Young OP, Edwards GB (1990). Spiders in United States field crops and their potential effect on crop pests. J. Arachnol. $1-27$. 